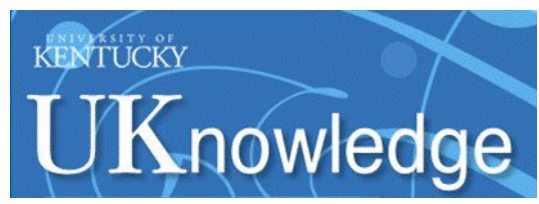

University of Kentucky

UKnowledge

$10-2018$

\title{
An Inquiry-Based Investigation of Bacterial Soft Rot of Potato
}

Robert Louis Hirsch

University of Kentucky, robert.hirsch@uky.edu

Seth Miller

Leestown Middle School

Dennis Halterman

USDA Agricultural Research Service

Follow this and additional works at: https://uknowledge.uky.edu/plantpath_facpub

Part of the Plant Pathology Commons

Right click to open a feedback form in a new tab to let us know how this document benefits you.

\section{Repository Citation}

Hirsch, Robert Louis; Miller, Seth; and Halterman, Dennis, "An Inquiry-Based Investigation of Bacterial Soft Rot of Potato" (2018). Plant Pathology Faculty Publications. 85.

https://uknowledge.uky.edu/plantpath_facpub/85

This Article is brought to you for free and open access by the Plant Pathology at UKnowledge. It has been accepted for inclusion in Plant Pathology Faculty Publications by an authorized administrator of UKnowledge. For more information, please contact UKnowledge@lsv.uky.edu. 


\title{
An Inquiry-Based Investigation of Bacterial Soft Rot of Potato
}

\author{
Digital Object Identifier (DOI)
}

https://doi.org/10.1525/abt.2018.80.8.594

\section{Notes/Citation Information}

Published in The American Biology Teacher, v. 80, no. 8, p. 594-599.

(C) 2018 National Association of Biology Teachers. All rights reserved.

Published as Hirsch, R. L., Miller, S., \& Halterman, D. (2018). An inquiry-based investigation of bacterial soft rot of potato. The American Biology Teacher, 80(8), 594-599. https://doi.org/10.1525/

abt.2018.80.8.594. Copying and permissions notice: Authorization to copy this content beyond fair use (as specified in Sections 107 and 108 of the U. S. Copyright Law) for internal or personal use, or the internal or personal use of specific clients, is granted by the National Association of Biology Teachers for libraries and other users, provided that they are registered with and pay the specified fee via Rightslink ${ }^{\circledR}$ or directly with the Copyright Clearance Center.

The copyright holder has granted the permission for posting the article here. 


\section{INQUIRY \&} INVESTIGATION
An Inquiry-Based Investigation of Bacterial Soft Rot of Potato
R. LOUIS HIRSCH, SETH MILLER, DENNIS HALTERMAN

\begin{abstract}
Inquiry-based investigations of diseases are often difficult to safely undertake in middle school or high school science courses. However, by utilizing potatoes as a mammalian analogue, important groups of pathogens can be investigated with common materials available from the local supermarket. This article provides information to guide the exploration of factors underlying the development of the potato disease bacterial soft rot, caused by Pectobacterium caratovorum, and allows students the freedom to develop and test their own hypotheses regarding the development of symptoms, the spread of pathogens, and the impact of host and environmental variables on the progress of disease.
\end{abstract}

Key Words: plant diseases; Pectobacterium caratovorum; inoculation; soilborne pathogens; Enterobacteriaceae; Next Generation Science Standards; student-driven inquiry.

\section{Introduction}

Plant diseases result in billions of dollars of losses to farmers every year. Most plant diseases are caused by pathogenic fungi, but viruses, nematodes (microscopic worms), parasitic plants, and bacteria also cause important diseases (Agrios, 2004). For a disease to impact a crop, three factors must be present at the same time: (1) a susceptible host, (2) a virulent pathogen, and (3) a conducive environment (Figure 1). Diseases often reduce harvest yield by limiting plant growth, but some pathogens infect the fruit, vegetables, or grains and render the products unmarketable with rots or by producing toxins.

A group of bacteria referred to as soft rot Enterobacteriaceae (a taxonomic family containing members of the genera Pectobacterium and Dickeya) are common soilborne microorganisms and major postharvest pathogens of many important agricultural products (Mansfield et al., 2012; Czajkowski et al., 2015). In the absence of a host, these bacteria exist in the soil and feed on organic materials (Pérombelon, 1992). As seeds are planted and grow throughout the season, the bacteria eventually come in physical contact with the plant during root growth or following rain-splash dispersal onto stems and leaves. The pathogenic bacteria attach to the plant during harvest and infest the products during shipment and storage. Infection typically occurs after the crop has been harvested, generally as a result of storage or shipment conditions that support disease development (Pérombelon \& Lowe, 1975; Johnson, 2015). During infection, Enterobacteriaceae produce enzymes called pectinases. Pectinases degrade pectins, which are important structural molecules of plant cell walls and are also involved in adhering plant cells together into tissues (Collmer \& Keen, 1986). When the bacteria infect a host, the tissue structure collapses as pectins are degraded, leading to the symptoms pathologists call soft rot, typified by softening of the infected tissue, often accompanied by discoloration and an overpowering odor.

Bacterial soft rot is an important postharvest disease of potatoes (and other fruits, vegetables, and decorative plants). Among the characterized species of Enterobacteriaceae that cause soft rot diseases, Pectobacterium carotovorum subspecies carotovorum (Pcc) has the widest host range. As a representative pathogen for the Enterobacteriaceae, Pcc adheres to the skin of potatoes as the tubers develop in the ground during the growing season. After harvest, potatoes often remain disease free unless they experience a wound during shipment (which allows the naturally present Pcc to penetrate the tuber) or if the potatoes are exposed to moisture (which allows Pcc to vigorously reproduce on the exterior of the potato and eventually infect; Czajkowski et al., 2015). Despite steps in the supply chain that reduce opportunities for infection, many consumers observe potato soft rot when potatoes are improperly stored in pantries or drawers for extended periods (Johnson, 2015).

The soft rot experiment described in this protocol was developed using elements of the Next Generation Science Standards (National Research Council, 2012; Table 1). The core protocol outlines the steps of acquiring primary inoculum and basic inoculation procedures. Additional protocol sections explore inquirybased experiments that allow students the freedom to investigate different components of the disease triangle on a seven-day schedule (Table 2). 
Virulent

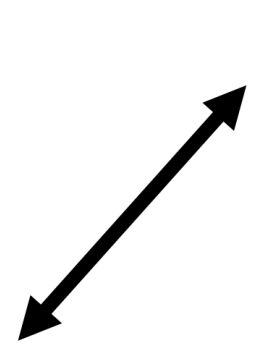

Pathogen

Disease

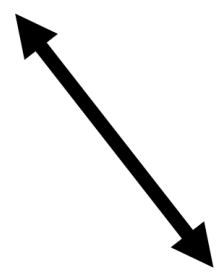

Susceptible

Host
Table 2. Proposed schedule of experiments with a seven-day incubation period.

\begin{tabular}{|l|l|}
\hline \multicolumn{1}{|c|}{ Day } & \multicolumn{1}{c|}{ Activity $^{\text {a }}$} \\
\hline 7 days before & $\begin{array}{l}\text { Set up culture to acquire inocula from a } \\
\text { cut and soaked potato. }\end{array}$ \\
\hline 1 day before & $\begin{array}{l}\text { Disinfest potatoes by soaking in a 10\% } \\
\text { bleach solution. }\end{array}$ \\
\hline Lab day 1 & Inoculate and incubate potatoes. \\
\hline Lab day 7 & $\begin{array}{l}\text { Observe the macro and microscopic } \\
\text { signs and symptoms of bacterial soft rot. }\end{array}$ \\
\hline Lab day 14 & $\begin{array}{l}\text { Brainstorm variables for the inquiry- } \\
\text { based protocol. Inoculate and incubate } \\
\text { plant samples. }\end{array}$ \\
\hline Lab day 21 & $\begin{array}{l}\text { Observe and measure the macro and } \\
\text { microscopic signs and symptoms of } \\
\text { bacterial soft rot. }\end{array}$ \\
\hline
\end{tabular}

${ }^{\mathrm{a}}$ For details, see text.
Figure 1. The disease triangle. For disease to occur, the environment must be conducive for a virulent pathogen to infect a susceptible host (adapted from Agrios, 2004).
Conducive Environment

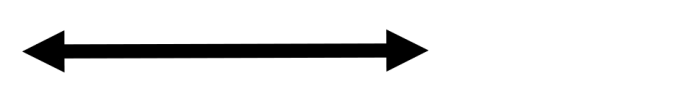




\section{Methods}

Throughout the protocol, utilize only conventionally grown (nonorganic) potatoes. Conventional potatoes are treated with a germination inhibitor, which will prevent potatoes from sprouting when incubated.

\section{Required Materials}

The following are needed for each lab group of two to four students:

- Potatoes (Russets are the most common; at least three for each group)

- Damp paper towels

- Sealable plastic bags

- Toothpicks

- Small beakers for the bacterial inoculum

- A $10 \%$ bleach solution containing two drops of dish soap per gallon

- A large container for disinfesting the potatoes in $10 \%$ bleach

- Microscopy equipment (microscopes with 400x magnification, slides, coverslips, metal probes)

- Optional: Latex or nitrile gloves (soft rot bacteria are not infectious to humans, but the odor could be a detriment with direct contact with skin)

\section{Core Protocol}

Performed by the teacher prior to the lab:

(1) A week prior to the experiments, initiate the cultures to acquire inoculum. Cut a potato in half and incubate the halves in an airtight plastic bag with $50 \mathrm{~mL}$ of tap water for five days at room temperature. If infected, the potato will be soft to the touch and the liquid will be cloudy with bacteria. Most potatoes will become infected with this approach, so consider incubating between three and five potatoes to collect sufficient inocula for the class.

(2) The day before the lab begins, disinfest the remaining potatoes by soaking in the $10 \%$ bleach solution for at least 30 minutes. Ensure that each potato is completely submerged in the bleach solution, and agitate the potatoes occasionally as they soak to remove any bubbles. After incubation, remove the potatoes from the bleach solution, rinse with fresh water, dry with paper towels, and set aside to air dry overnight.

(3) Prior to the start of class:

(a) Mock inoculate (with water) at least three disinfested potatoes as negative (healthy) controls. Inoculate each potato with a clean toothpick, wrap in a damp paper towel, and incubate in the same manner as the students' samples.

(b) Collect the bacterial inoculum by cutting a corner of the culture bag and collecting the liquid in several containers for the students. The bacteria can be stored in a refrigerator and used for at least six weeks.

Performed by the students:

(1) Discuss and outline the experiment (Table 3).
Table 3. Experimental design scaffold (including representative discussion points for students).

\begin{tabular}{|l|l|}
\hline Question & $\begin{array}{l}\text { What conditions impact the } \\
\text { development of potato soft } \\
\text { rot? }\end{array}$ \\
\hline $\begin{array}{l}\text { Hypothesis } \\
\text { ("If. . then. . because") }\end{array}$ & $\begin{array}{l}\text { If we inoculate a potato with } \\
\text { soft-rot-causing bacteria, } \\
\text { then \% of the potatoes } \\
\text { will be infected with bacteria } \\
\text { because }\end{array}$ \\
\hline Materials & (See text) \\
\hline $\begin{array}{l}\text { Independent Variables } \\
\text { (What you changed on } \\
\text { purpose; this is the } \\
\text { experimental group) }\end{array}$ & $\begin{array}{l}\text { Inoculated healthy potatoes } \\
\text { with soft rot bacteria }\end{array}$ \\
\hline $\begin{array}{l}\text { Dependent Variables } \\
\text { (How you measured what } \\
\text { changed) }\end{array}$ & $\begin{array}{l}\text { Percentage of the potato } \\
\text { (either surface, interior, or } \\
\text { total potato) that exhibits } \\
\text { symptoms of soft rot. }\end{array}$ \\
\hline $\begin{array}{l}\text { Constant Variables } \\
\text { (Also called constants; add } \\
\text { as many as needed) }\end{array}$ & $\begin{array}{l}\text { Moisture, temperature, } \\
\text { disinfested potatoes, potato } \\
\text { variety, etc. }\end{array}$ \\
\hline $\begin{array}{l}\text { Control Group } \\
\text { (The normal condition; what } \\
\text { you compare your } \\
\text { experimental group and } \\
\text { independent variable to) }\end{array}$ & $\begin{array}{l}\text { Healthy, surface-disinfested } \\
\text { potatoes. }\end{array}$ \\
\hline
\end{tabular}

(2) For each lab group of two to four students, collect at least three disinfested potatoes and ensure that they are free of obvious disease symptoms incurred during shipment and storage.

(3) Dip a clean toothpick into a container of bacterial solution and inoculate the bacteria into the potato by poking the toothpick through the skin. Repeat the inoculation approach to ensure that each potato is similarly inoculated (i.e., a similar number of toothpick wounds). The same toothpick may be used for all the inoculations, but students must re-dip the toothpick in the bacteria solution prior to each inoculation for consistency.

(4) After inoculating, wrap each potato in damp paper towels and enclose in a sealable plastic bag.

(5) Incubate all potatoes on the benchtop for seven days. If infected, the potatoes will become soft to the touch and produce a pungent odor.

(6) Analysis:

(a) Record which inoculation approach (control or experimental) yielded the most disease symptoms (Figure 2). Since each group inoculated three potatoes, each lab group's samples should exhibit similar symptoms.

(b) Slice the potatoes through lesions and observe symptoms within the potato (Figure 2B-D).

(7) After the plant tissue becomes infected, collect diseased tissue and observe with a sample of healthy tissue as a comparison 

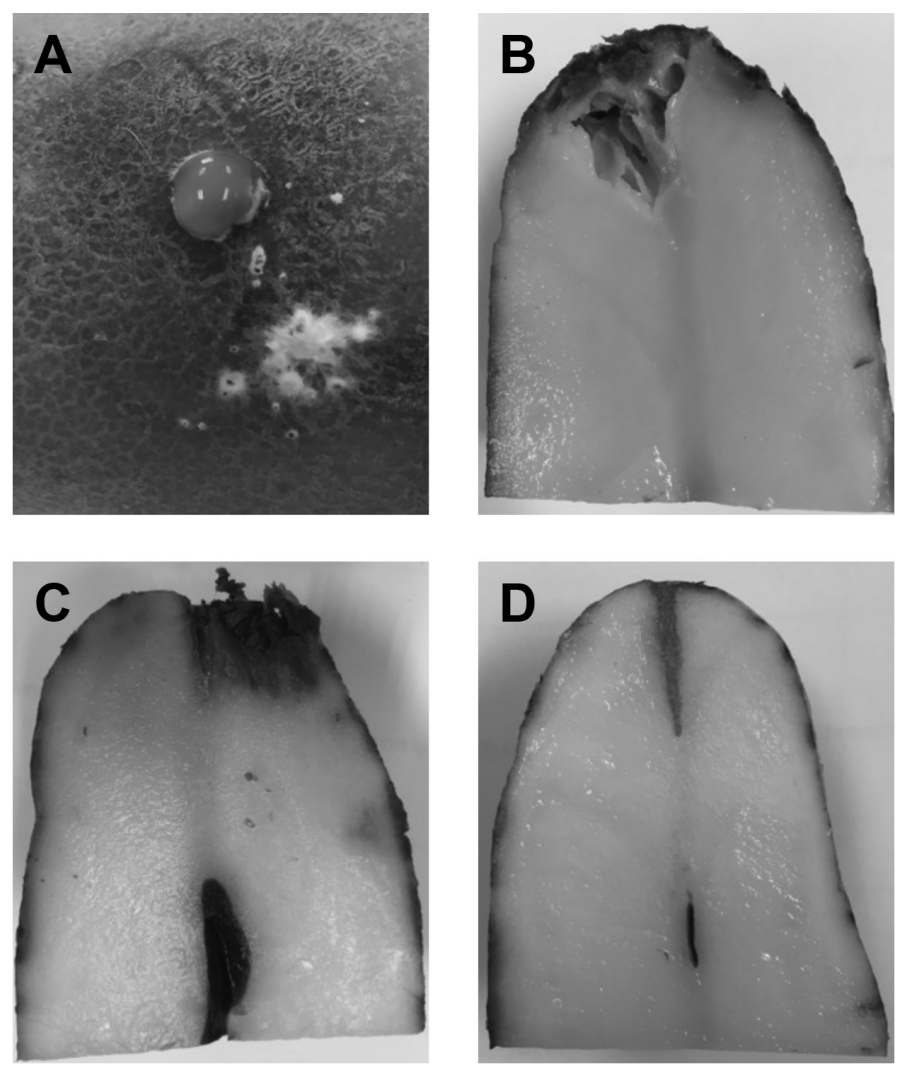

Figure 2. Signs and symptoms of bacterial soft rot.

(A) Bacteria from the toothpick wound are accompanied by a dark halo of diseased, softened tissue. The white organism is a fungus, which is a common contaminant and not involved in the disease. (B) A bisected potato lesion exhibiting tissue collapse without any secondary darkening. (C) A bisected, darkened potato lesion on the margin of the tuber. The black lesion in the center of the potato is an abiotic disorder called hollow heart, which is caused by incubation in moist environments and is not related to soft rot. (D) A bisected mock-inoculated potato, exhibiting cork formation at the inoculation site. Note the small hollow heart lesion near the center of the potato.

with a microscope. Bacteria are very small and will be only faintly visible at $400 \times$ magnification. With potato samples, amyloplasts (organelles that contain starches) are visible as clear, bean-shaped structures. The bacteria should be visible as a diffuse mass that is similar to television static (Figure 3).

\section{Inquiry-Based Protocol Amendments Organized by the Disease Triangle}

Prior to embarking on additional experiments, promote studentdriven inquiry by posing the following scenarios to the lab groups. Ask the lab groups to brainstorm answers to the questions, and then encourage each group to share their answers with the whole class to generate a list of experimental variables. Due to time constraints, consider preparing your own variables prior to class that can be investigated immediately.

Susceptible host:

(1) Inoculate different hosts. There are several species of bacteria that cause soft rot, and each species has a different host preference. Since different potato varieties share common characteristics, will a pathogen isolated from one variety of potato be able to infect another variety of potato? Will a pathogen isolated from a potato be able to infect other fruits and vegetables?

(a) Inoculate different potato varieties such as Yukon Gold, Russet Burbank, Red Pontiac, or any other commercially available varieties. Consider selecting smaller potato varieties to optimize space use in the classroom.

(b) Inoculate different susceptible plant products such as carrots, green bell peppers, bananas, apples, tomatoes, and cucurbits (i.e., cucumbers, squashes, pumpkins; summarized in Bhat et al., 2010).

(2) Utilize different inoculation approaches. Sometimes potatoes are damaged during shipment from the farm to the store. If a truckload of potatoes is transported across the country, what are some injuries that are likely to occur?

(a) Dip a whole potato in the inoculum solution.

(b) Prior to application of inoculum, damage the host tissue by abrading, crushing, or superficial wounding to simu-

late damage that commonly occurs during shipment.
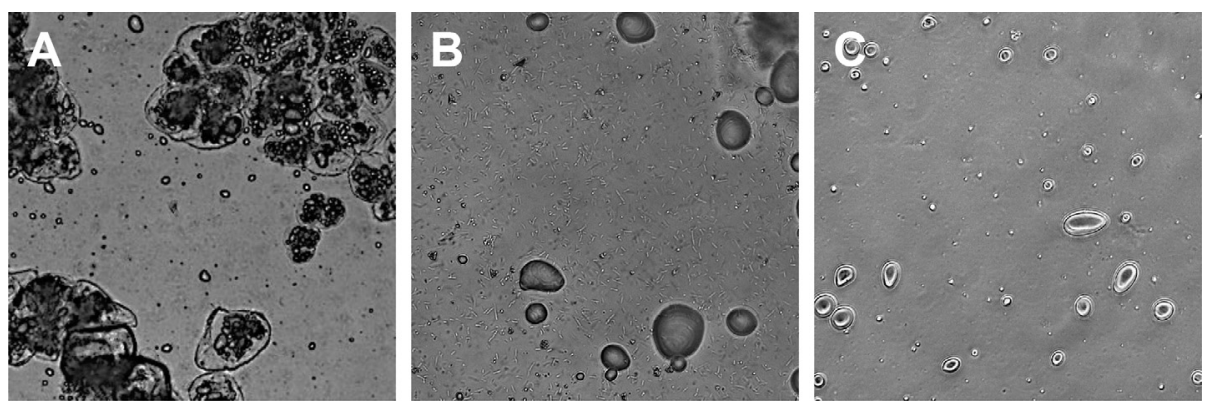

Figure 3. Micrographs of healthy and diseased potato. A small piece of tissue was visualized with a microscope at different magnification without stain. (A) At 200x, potato cell debris and amyloplasts (the dark, bean-shaped structures) are visible, but bacteria are difficult to observe. (B) Infected tissue viewed at 400x shows scattered amyloplasts surrounded by many bacilliform bacteria. (C) By contrast, healthy tissue viewed at 400x shows scattered amyloplasts without associated bacteria.
Conducive environment:

(1) Alternate the temperature. In nature, $\mathrm{Pcc}$ is most active at $10-20^{\circ} \mathrm{C}\left(50-68^{\circ} \mathrm{F}\right)$, but soft rot often occurs at warmer temperatures during shipment or storage in a warm pantry. What effect will different temperatures have on the development of disease?

(a) Alter the incubation temperature (room temperature vs. warm temperature) or temperature extremes (hot vs. cold).

(2) Modify water availability. If the potatoes were harvested following a rainstorm and were loaded into a truck wet, 
how would the increased moisture impact the environment during shipment?

(a) The availability of water is a critical environmental variable for disease development. Consider creating different humid environments with damp paper towels, plastic bags, or airtight containers.

(3) Alter light exposure. After buying potatoes at the supermarket, they are often stored in a dark pantry. What may happen if the potatoes are stored in sunlight or under classroom lights compared to the dark?

(a) Although less well characterized by scientists, consider altering the exposure to light (dark vs. florescent vs. sunlight) or the color of the light by wrapping containers in different colors of plastic.

Virulent pathogen:

(1) Alternate sources of inoculum. Bacterial soft rot pathogens are often adapted to their hosts. Given soft rot bacteria from different hosts, which do you think will most likely be able to infect potatoes and why?

(a) Gather inocula from different hosts, and inoculate on disinfested potatoes. For example, collect inocula from bell pepper, carrot, and cucumber utilizing the same technique as outlined for the core protocol and investigate which pathogen is most virulent on potato. Inocula from non-potato hosts can be inoculated into healthy potatoes utilizing the protocol outlined previously. Enterobacteriaceae are known to infect numerous varieties of plants, and there are many resources that list the known host species (Bhat et al., 2010).

\section{Discussion}

The most practical consideration with this laboratory exercise is managing the odor during incubation. Since disease symptoms are best analyzed between five and seven days after inoculation, culture incubation in a well-ventilated area is encouraged. For example, consider incubating potatoes in a chemical fume hood (if available) or near an open window with an exhaust fan. Furthermore, the odor in the classroom should be mitigated prior to class because disruptive behavior (especially for middle school students) often increases in laboratories with pungent odors. Although the bacteria cultured in this experiment are not human pathogens, instructors should exhibit best laboratory practices, including providing eye protection, gloves, and protective garments for the students. Since soft rot bacteria are naturally occurring, most locations do not require special waste procedures.

Expect to observe a variety of results during this laboratory experiment, since each lab group will inoculate and incubate their potatoes differently. For example, humidity is a critical variable for disease development, and some lab groups may not adequately wet their paper towels or sufficiently seal their plastic bags prior to incubation. Lack of sufficient moisture often results in asymptomatic potatoes, even when inoculated with the pathogen. Also, symptoms exist on a spectrum and often appear differently between inoculations. Common symptoms are tissue softness (superficial or very deep within the potato) and discoloration (tan to nearly black; Figure 2B, C).
These symptoms should not be confused with hollow heart, which is a blackening of the center of the potato in response to increased moisture, or cork formation, which is a natural scab-like tissue layer that often surrounds the toothpick wound when viewed on a potato cross section (Figure 2C, D). Lastly, fungi often contaminate wounded potatoes and are visible as a fuzzy mass commonly associated with the inoculation site (Figure 2A). These fungi are most likely not causing disease, but rather feeding on the dead potato tissue.

The microscopic analysis of infected tissue often yields unclear results due to insufficient magnification. Prior to viewing a diseased sample, consider instructing the students to view healthy potato tissue first so they become familiar with the components of potato cells. The most visible component of potato cells without specialized staining are the amyloplasts, which are the plastids that store starch (Figure 3). Each potato cell contains numerous amyloplasts, which appear as bean-shaped structures with dark margins. In the healthy sample, the liquid between the amyloplasts should be clear. When viewing the diseased sample, remember that bacteria are small (generally 1-2 $\mu \mathrm{m}$ in length) and are often difficult to observe individually. Bacteria are only faintly visible at $400 \times$ magnification and may require dimming the illumination on the microscope to identify them. Since the infected tissue should contain vast quantities of bacteria, the pathogens should be visible as an opaque, shifting layer (resembling television static) between amyloplasts.

Students often experience difficulties with the nuanced vocabulary associated with plant pathology, but an explanation of the following words and their definitions will likely lead to increased content comprehension.

Pathogens vs. disease. Diseases are disruptions in normal cellular function. Diseases can be caused by abiotic (nonliving) factors like nutrient deficiencies or by biotic (living) factors like bacterial pathogens. Pathogens are the causal agents of disease. In this laboratory protocol, the Enterobacteriaceae are the pathogens, and soft rot is the disease.

Signs vs. symptoms. Symptoms are the physiological host responses associated with pathogen infection. For example, symptoms of infection by soft-rot-causing bacteria on potato are soft rot, discoloration, and a pungent odor. Signs of an infection are the pathogens, which in this experiment are bacteria that can be observed only under high magnification on a compound microscope or as ooze flowing out of lesions.

Infect vs. infest. Infection is the initiation of a parasitic relationship with a host, whereas infestation is to reside on the exterior of a surface without infecting. Nearly all potatoes are infested with Enterobacteriaceae from the soil; however, potatoes can remain healthy in storage for many weeks until the environment becomes conducive for pathogen infection.

Pathogenicity vs. virulence. Pathogenicity is a categorical variable (i.e., yes or no) describing whether an organism can cause disease. Virulence is a continuous variable (i.e., from 1 to 10) that describes the symptom severity. For example, a species of bacteria may be pathogenic on potatoes but exhibit moderate virulence.

The inquiry-based protocol may take numerous directions depending on which variables are tested. When designing each experiment, ensure that mock-inoculated disinfested potatoes serve as controls for each different approach. When investigating pathogen virulence, note that this protocol does not necessarily involve a pure culture. When the inoculum is initially generated for the experiment, 
it is possible that different species of bacteria are infesting the plant tissue at the same time and reproduce during incubation. Therefore, the inquiry-based pathogen virulence experiment may be complicated by a mixed culture of inoculum, which may yield conflicting results across repeated trials. Also, the bleach disinfestation technique is not $100 \%$ effective at eliminating all bacteria, so some of the mock-inoculated potatoes may exhibit soft rot. Unexpected symptoms may be critically discussed by the students as they troubleshoot their experiments.

\section{Additional Resources}

Additional support material and tutorial videos are available at http://www.drlouhirsch.com.

\section{Acknowledgments}

We thank Pramita Basnal for her assistance with testing experimental conditions related to inoculation and incubation with soft rot bacteria.
Czajkowski, R., Pérombelon, M.C.M., Jafra, S., Lojkowska, E., Potrykus, M., van der Wolf, J.M. \& Sledz, W. (2015). Detection, identification and differentiation of Pectobacterium and Dickeya species causing potato blackleg and tuber soft rot: a review. Annals of Applied Biology, 166, $18-38$.

Johnson, S.B. (2015). Blackleg and bacterial soft rot. University of Maine Cooperative Extension Bulletin 2493. Retrieved from https://extension. umaine.edu/publications/2493e/.

Kentucky Department of Education (2015). Kentucky Academic Standards: June 2015. Retrieved from https://education.ky.gov/curriculum/ standards/kyacadstand/Documents/Kentucky\%20Academic\% 20Standards_Final-9\%2011\%2015.pdf.

Mansfield, J., Genin S., Maģori S., Citovsky V., Sriariyanum, M., Ronald, P. et al. (2012). Top 10 plant pathogenic bacteria in molecular plant pathology. Molecular Plant Pathology, 13, 614-629.

National Research Council (2012). A Framework for K-12 Science Education: Practices, Crosscutting Concepts, and Core Ideas. Washington, DC: National Academies Press.

Pérombelon, M.C.M. (1992). Potato blackleg: epidemioloğy, host-pathogen interaction and control. Netherlands Journal of Plant Pathology, 98 (Supplement 2), 135-146.

Pérombelon, M.C.M. \& Lowe, R. (1975). Studies on the initiation of bacterial soft rot in potato tubers. Potato Research, 18, 64-82.

\section{References}

Agrios, G.N. (2004). Plant Pathology, $5^{\text {th }}$ Ed. San Diego, CA: Academic Press. Bhat, K.A., Masood, S.D., Bhat, N.A., Bhat, M.A., Razvi, S.M., Mir, M.R. et al. (2010). Current state of post harvest soft rot in vegetables: a review. Asian Journal of Plant Sciences, 9, 200-208.

Collmer, A. \& Keen, N.T. (1986). The role of pectic enzymes in plant pathogenesis. Annual Review of Phytopathology, 24, 383-409.

R. LOUIS HIRSCH is a Lecturer in the Department of Plant Pathology at the University of Kentucky, 201F Plant Science Building, 1405 Veterans Dr., Lexington, KY 40546-0312; email: robert.hirsch@uky.edu. SETH MILLER is a Science Teacher at Leestown Middle School, 2010 Leestown Rd., Lexington, KY 40511; email: seth.miller@fayette.kyschools.us. DENNIS HALTERMAN is a Research Geneticist in the U.S. Department of Agriculture, Agricultural Research Service Vegetable Crops Research Unit, 1575 Linden Dr., Madison, WI 53706-1514; email: dennis.halterman@ars.usda.gov.

When it comes to your degree,
it's best to do the research.
Earn a master's degree that combines research skills, advanced expertise,
and effective teaching strategies for your biology classroom.
- Accredited degree from a leader in graduate education
- Fully online program you can complete while teaching
- Research experience to solve modern biological problems
- 40+ elective courses in a variety of specialized topics
APPLY NOW to get started on your graduate degree!
Nebraskí. For more information, visit msbio.unk.edu
Online or email msbiology@unk.edu

